University of Nebraska - Lincoln

DigitalCommons@University of Nebraska - Lincoln

2020

\title{
Molecular Gut-Content Analysis of Adult Ground Beetles (Coleoptera: Carabidae) Provides No Evidence of Predation of Western Corn Rootworm (Coleoptera: Chrysomelidae) in a Nebraska Corn Agroecosystem
}

Camila Oliveira-Hofman

Vinícius S. Victor

Lance Meinke

Julie A. Peterson

Follow this and additional works at: https://digitalcommons.unl.edu/entomologyfacpub

Part of the Entomology Commons

This Article is brought to you for free and open access by the Entomology, Department of at

DigitalCommons@University of Nebraska - Lincoln. It has been accepted for inclusion in Faculty Publications:

Department of Entomology by an authorized administrator of DigitalCommons@University of Nebraska - Lincoln. 


\title{
Molecular Gut-Content Analysis of Adult Ground Beetles (Coleoptera: Carabidae) Provides No Evidence of Predation of Western Corn Rootworm (Coleoptera: Chrysomelidae) in a Nebraska Corn Agroecosystem ${ }^{1}$
}

\author{
Camila Oliveira-Hofman, Vinícius S. Victor ${ }^{3}$, Lance J. Meinke, and Julie A. \\ Peterson $^{2}$
}

Department of Entomology, University of Nebraska-Lincoln, Lincoln, Nebraska 68583 USA

\begin{abstract}
J. Entomol. Sci. 55(4): 448-461 (October 2020)
Abstract This study was conducted to characterize the ground beetle (Coleoptera: Carabidae) community in Nebraska continuous cornfields and investigate the potential for predation of the western corn rootworm, Diabrotica virgifera virgifera LeConte, a key rootfeeding insect pest that is an annual management challenge in this system. Seven collection dates were conducted at five commercial cornfields in west central Nebraska during the growing season of 2014. In each field, carabids were sampled using five 24-h pitfall traps. Carabid specimens were placed in $95 \%$ ethanol in the field and stored at $-20^{\circ} \mathrm{C}$ to preserve DNA. After identification to the species level, DNA was extracted and polymerase chain reaction was conducted for gut-content analysis using $D$. v. virgifera-specific primers. Data from single-plant emergence cages and yellow sticky cards showed high abundance of $D$. $v$. virgifera prey in three of the five fields sampled. Sixteen genera and 36 carabid species were found in pitfall traps. Of the total 235 carabid specimens tested in this study, zero tested positive for $D$. $v$. virgifera DNA. The lack of positive results for the presence of $D$. $v$. virgifera DNA in the gut-contents of carabids, despite abundant pest populations, indicates that, in this system, ground beetles may not be a strong mortality agent of $D$. v. virgifera. However, results presented here contribute to our knowledge of carabid diversity in agroecosystems and indicate that future $D$. $v$. virgifera biological control efforts in this region should focus on other natural enemies and/or other life stages of carabids, such as larvae.
\end{abstract}

Key Words Carabidae, Diabrotica virgifera virgifera, rootworm, molecular gut-content analysis, field corn

Ground beetles (Coleoptera: Carabidae) are ubiquitous members of agroecosystems and have been linked to arthropod pest and weed management (Holland and Luff 2000, Kromp 1999, Lövei and Sunderland 1996). In cornfields, carabids are abundant and are compatible with transgenic insecticidal hybrids, as they are not negatively impacted by Bacillus thuringiensis (Bt) Berliner toxins (Ahmad et al. 2006, Álvarez-Alfageme et al. 2009, Duan et al. 2006, French et al.

\footnotetext{
${ }^{1}$ Received 25 September 2019; accepted for publication 8 November 2019.

${ }^{2}$ Corresponding author (email: julie.peterson@unl.edu), West Central Research \& Extension Center, University of Nebraska-Lincoln, North Platte, Nebraska, 69101, USA.

${ }^{3}$ Department of Crop Protection, College of Agronomic Sciences, São Paulo State University, Botucatu, São Paulo, Brazil.
} 
2004, Leslie et al. 2009, Mullin et al. 2005, Peterson et al. 2009). There have been numerous studies of the biology and ecology of carabids in the Midwestern United States (see McCravy and Lundgren 2011 and references therein). However, carabid ecology and distribution, and their potential for providing pest suppression in Nebraska, are largely unknown as few researchers have investigated ground beetles in Nebraska agroecosystems (Hariharan 1988, Pretorius et al. 2017).

The western corn rootworm, Diabrotica virgifera virgifera LeConte (Coleoptera: Chrysomelidae), is the main root-feeding pest of continuous corn (Zea mays L.) production in the United States and Europe. This pest is present in the field all year. Eggs typically start hatching in late May (Meinke et al. 2009) and go through three larval instars and a pupal stage before adult emergence. Adults emerge from the end of June through September, with delayed mean emergence periods occurring in transgenic Bt hybrid fields (Hitchon et al. 2015). Oviposition occurs from July to September (Meinke et al. 2009). Corn is the primary host of $D$. v. virgifera (Clark and Hibbard 2004) and, therefore, this pest is mainly a problem in continuous corn, except in limited geographic regions where behavioral resistance to rotation has occurred (Gray et al. 2009).

Current management tactics for $D$. $v$. virgifera include crop rotation, insecticidal seed treatments, soil and foliar insecticides, and transgenic Bt hybrids. Continuous corn production requires constant pest management and, because of the high management pressure and the adaptive nature of this pest (Gray et al. 2009, Miller et al. 2009), populations of $D$. v. virgifera have evolved resistance to a variety of management practices. Resistance or reduced susceptibility has been reported with crop rotation (Levine et al. 2002); with chemical insecticides, such as organochlorines (Parimi et al. 2006), pyrethroids (Pereira et al. 2015; Souza et al. 2019), organophosphates, and carbamates (Meinke et al. 1998); and with Bt proteins such as Cry3Bb1 (Gassmann et al. 2011), with cross resistance to mCry3A (Gassmann et al. 2014) and eCry3.1Ab (Zukoff et al. 2016), and most recently Cry34/35Ab1 (Gassmann et al. 2016). Management of D. v. virgifera populations and resistance issues requires a complex integrated pest management (IPM) approach. Due to the frequency and severity of resistance to current management tactics, investigation of $D$. v. virgifera biological control is critical and may lead to an additional management option to integrate with current $D$. $v$. virgifera control practices.

In the $D$. $v$. virgifera system, no keystone predator has been identified, although a variety of arthropod predators have been reported to prey on the different life stages of this pest in laboratory and/or field conditions, as reviewed by Kuhlmann and Van der Burgt (1998) and Toepfer et al. (2009). Molecular gut-content analyses indicate that several species of Carabidae can prey on $D$. v. virgifera eggs and larvae (Lundgren et al. 2009, Lundgren and Fergen 2014). Larvae and adults of Scarites quadriceps Chaudoir as well as adult Poecilus chalcites (Say) had relatively high consumption rates and predation frequencies on $D$. $v$. virgifera immatures as 20.4 and $17.5 \%$ of individuals of each species tested positive for $D$. $v$. virgifera DNA in gut-content analyses (Lundgren et al. 2009). However, visual observations indicated that Carabidae are incidental predators of rootworms, with predation dependent upon chance encounters instead of active prey search (Kirk 1982). Therefore, while some carabids have been confirmed as $D$. $v$. virgifera predators, their role in biological control is largely unknown. However, in conjunction 
with other pest management strategies already in place, predators may provide an additional tool to minimize population pressure and resistance issues.

Nebraska is the third largest corn producer in the United States (USDA-National Agricultural Statistics Service 2017) and D. v. virgifera is one of the state's most critical insect pests. Predation of any life stage of this pest can aid plant protection in the long term since this is a continuous corn pest. Therefore, the objectives of this study were to (a) characterize the community of carabids from commercial cornfields and (b) identify potential carabid predators of $D$. $v$. virgifera via molecular gut-content analysis.

\section{Materials and Methods}

Field sites. This study was conducted in 2014 on five no-till, irrigated cornfields in Keith County (Field A: N 41 $07^{\prime}, \mathrm{W} 101^{\circ} 39^{\prime} \mathrm{W}$ ) and Perkins County (Field B: N

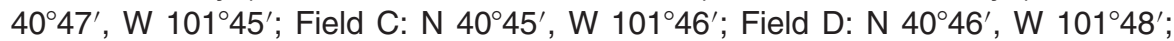
Field E: N 40 $51^{\prime}$, W $101^{\circ} 42^{\prime}$ ) in west central Nebraska. Four fields (A-D) had been continuous cornfields for at least $5 \mathrm{yr}$ and had a history of high $D$. v. virgifera pressure and one field $(E)$, was first-year corn with low $D$. v. virgifera pressure. Fields A-D were planted to corn hybrids expressing rootworm-active Bt proteins (Cry3Bb1 and/or Cry34/35Ab1) and Field E was planted to a corn hybrid that did not express rootworm-active proteins. All fields were maintained under agronomic practices standard for the region.

Collection of $\boldsymbol{D}$. v. virgifera. All fields were surveyed for prey availability on seven dates throughout the corn-growing season (June-September). In each field, four unbaited Pherocon ${ }^{\circledast}$ AM yellow sticky cards (YSC) (Hein and Tollefson 1985) were placed at canopy height at early vegetative stages and then placed at ear height for the remainder of the season. YSCs were left in the field for $7 \mathrm{~d}$ and then were placed in the refrigerator until processing. In addition, rootworm densities were also monitored in each field with eight single-plant adult emergence cages (Pierce and Gray 2007) per field. Emergence cages were checked weekly during the adult emergence period from 15 July 2014 to 26 September 2014, for a total of 11 collection dates. Sampling units (YSC and emergence cages) were placed 8 to 15 $\mathrm{m}$ from each other and were located between $60-120 \mathrm{~m}$ from the edge of the field.

Carabid collection for molecular gut-content analysis. Five dry pitfall traps were located at each field: four inside the irrigated cornfield and one in the nonirrigated border. Traps were opened for $24 \mathrm{~h}$ per collection period. Each trap was sampled every other week from 11 June 2014 to 3 September 2014 for a total of seven collection dates. On average, traps were opened around 12:00 p.m. and closed at 12:00 p.m. the next day. A hardware cloth insert (3.2-mm mesh) was placed inside dry pitfall traps (946 ml volume, $11.5 \times 14 \mathrm{~cm} \mathrm{WxH})$ (Eskelson et al. 2011) to prevent larger predators from consuming smaller arthropods. Arthropods trapped in the dry pitfall were individually placed into $1.5-\mathrm{ml}$ microcentrifuge tubes (Fisherbrand $^{\mathrm{TM}}$, Pittsburgh, PA) and preserved in 95\% ethanol in the field. The samples were then labeled and placed into an Engel 40 portable freezer (Big Frog Mountain, Chattanooga, TN) in the field, and subsequently frozen at $-20^{\circ} \mathrm{C}$ until analysis. Morphological identification was conducted for each specimen prior to 
DNA extraction using dichotomous keys of Arnett and Thomas (2000) and Lindroth (1961-1969).

Molecular gut-content analysis. Gut-content DNA extractions were performed using QIAGEN DNeasy Blood \& Tissue Kits (QIAGEN Inc., Chatsworth, CA). Specimens under $1.0 \mathrm{~cm}$ were extracted whole and specimens larger than $1.0 \mathrm{~cm}$ had gut dissections performed prior to DNA extraction. Polymerase chain reactions (PCRs) were conducted with a T100 Bio-Rad thermocycler (Bio-Rad Laboratories, Inc., Hercules, CA) with a D. v. virgifera-specific primer pair (E-F364 and G-R358) targeting the cytochrome $c$ oxidase I (COI) gene (Peterson 2012). The primer set was tested against eggs $(n=5)$, larvae $(n=2)$, and adults $(n=5)$ of $D$. v. virgifera to ensure that it could amplify all stages of this pest. Each PCR reaction contained $17.4 \mu \mathrm{l}$ of PCR-grade water, $2.5 \mu \mathrm{l} 10 \times$ Takara buffer (Takara Bio Inc., Shiga, Japan), $2.0 \mu \mathrm{l}$ Takara dNTPs, $0.5 \mu \mathrm{l}$ of each primer, $0.125 \mu \mathrm{l}$ Takara Taq Polymerase, and $2.0 \mu \mathrm{l}$ of DNA template per sample. PCR cycling protocol included an initial denaturation step at $94^{\circ} \mathrm{C}$ for $1 \mathrm{~min}$; then 45 cycles of denaturation at $94^{\circ} \mathrm{C}$ for $45 \mathrm{~s}$, annealing at $66^{\circ} \mathrm{C}$ for $45 \mathrm{~s}$, and extension at $72^{\circ} \mathrm{C}$ for $30 \mathrm{~s}$; and final extension at $72^{\circ} \mathrm{C}$ for $10 \mathrm{~min}$. Gel electrophoresis amplification verification was performed on $2 \%$ agarose gels in $1 \times$ Tris-acetate-EDTA buffer stained with GelRed $^{\text {TM }}$ Nucleic Acid Gel Stain (Biotium, Hayward, CA). Visualization of gels was conducted on GelDoc ${ }^{\mathrm{TM}} \mathrm{XR}+$ Gel Documentation system (Bio-Rad Laboratories Inc.).

Data analysis. Western corn rootworm beetle densities (emergence cage and YSC) were analyzed with SAS (SAS Institute Inc., version 9.4, Cary, NC). Data were fitted to negative-binomial distributions (Tripathi 2006) and analyzed with PROC GLIMMIX. One-way analyses of variance were used to analyze field differences in mean adult $D$. v. virgifera cumulative counts (between beginning and end collection dates) per emergence cage or per YSC. Mean estimates and multiple-mean comparisons were obtained with LSMEANS and t-grouping differences were obtained with the LINES option. Mean differences were considered significant at the $P<0.05$ level.

\section{Results}

Diabrotica virgifera virgifera density. There was a significant field effect on mean $D$. v. virgifera densities per emergence cage $\left(F_{4,35}=20.63, P<0.0001\right)$ and per YSC $\left(F_{4,15}=45.29, P<0.0001\right)$. Mean $( \pm$ SEM) cumulative $D$. v. virgifera per emergence cage was higher for Field $A(48.9 \pm 12.8)$ and Field $C(33.2 \pm 8.8)$, followed by Field $B(15.4 \pm 4.2)$, then Field D $(4.2 \pm 1.3)$, and lastly Field $E(1.4 \pm$ $0.5)$ (Fig. 1). The mean number of cumulative $D$. v. virgifera beetles per YSC was higher for Field $A(358.7 \pm 83.4)$ and Field $C(233.0 \pm 54.4)$, followed by Field $B$ $(31.7 \pm 7.8)$ and Field D (20.7 \pm 5.3$)$, and lastly Field E (2.5 \pm 1.0$)$ (Fig. 2).

Carabid and gut-content analysis. A total of 235 adult carabids were collected, identified, and screened using molecular gut-content analysis to detect $D$. $v$. virgifera DNA (Table 1). The two sampling dates in June yielded $16 \%$ of all specimens, in July the two sampling dates yielded $38 \%$ of all specimens. In August the two sampling dates yielded $21 \%$ of all specimens and the single date in early September yielded $25 \%$ of all specimens (Fig. 3). Thirty-six species were identified 


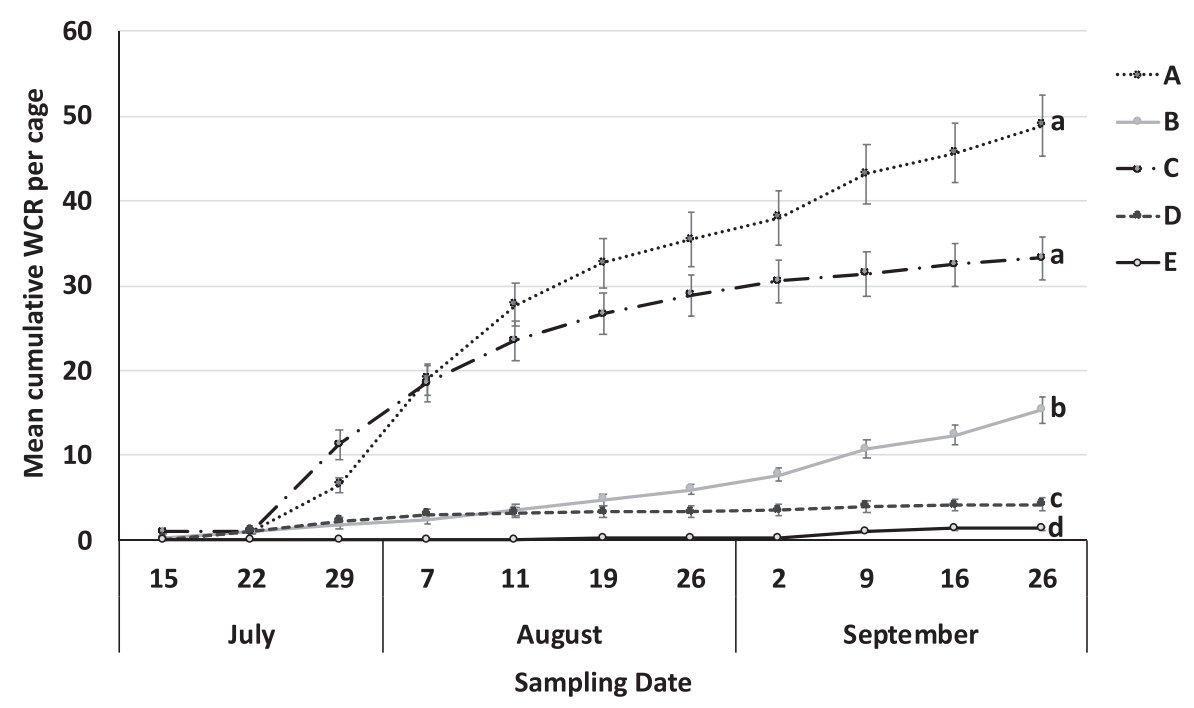

Fig. 1. Mean cumulative western corn rootworm (Diabrotica virgifera virgifera) adults per emergence cage. Error bars indicate \pm standard error of the mean. Uppercase letters represent cornfields A-E. One-way analysis of variance from cumulative values on 26 September revealed significant field effects $\left(F_{4}, 35=20.63, P<0.0001\right)$ on mean cumulative $D$. $v$. virgifera beetles per emergence cage $(n=8)$. Means with different lowercase letters are significantly different $(P<0.05)$.

belonging to 16 genera. The most diverse genus was Harpalus with 10 species, followed by Anisodactylus, Bembidion, and Agonum, each with 4 species. The three most abundant species collectively made up 66\% (155/235) of all Carabidae collected (i.e., Anisodactylus sanctaecrucis (F.) (27.7\%), Elaphropus anceps LeConte (21.7\%), and Bembidion quadrimaculatum L. (16.6\%); Table 1). Harpalus species were also quite abundant and constituted $15 \%(35 / 235)$ of the specimens found (Table 1).

None of the 235 Carabidae specimens tested positive for D. v. virgifera DNA using gut-content analysis with the E-F364 and G-R358 primer pair. However, the primer test yielded strong positive results for all $D$. $v$. virgifera life stages, indicating successful prey DNA amplification by this primer set. In addition, all predator extractions were screened with general COI primers that amplify DNA from members of Arthropoda (LCO-1490 and HCO-700dy; Folmer et al. 1994) to ensure that DNA extraction had been completed successfully and eliminate any potential false negative results. All carabids tested positive when subjected to the general arthropod COI screen.

\section{Discussion}

The carabid abundance data reported herein add to our knowledge of ground beetles in agroecosystems and specifically in the no-till continuous cornfield system 


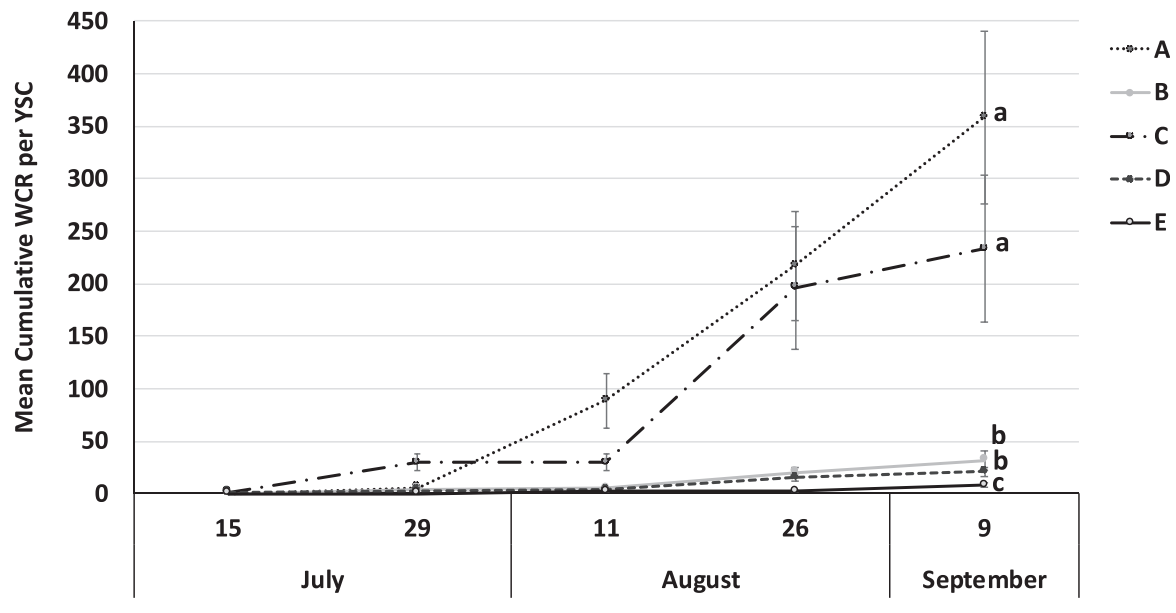

Sampling Date

Fig. 2. Mean cumulative western corn rootworm (Diabrotica virgifera virgifera) adults per yellow sticky card. Error bars indicate \pm standard error of the mean. Uppercase letters represent cornfields A-E. One-way analysis of variance from cumulative counts at 9 September revealed significant field effects $\left(F_{4,15}=45.29, P>F<0.0001\right)$ on mean $D$. $v$. virgifera beetles per yellow sticky card $(n=4)$. Means with different lowercase letters are significantly different $(P<0.05)$.

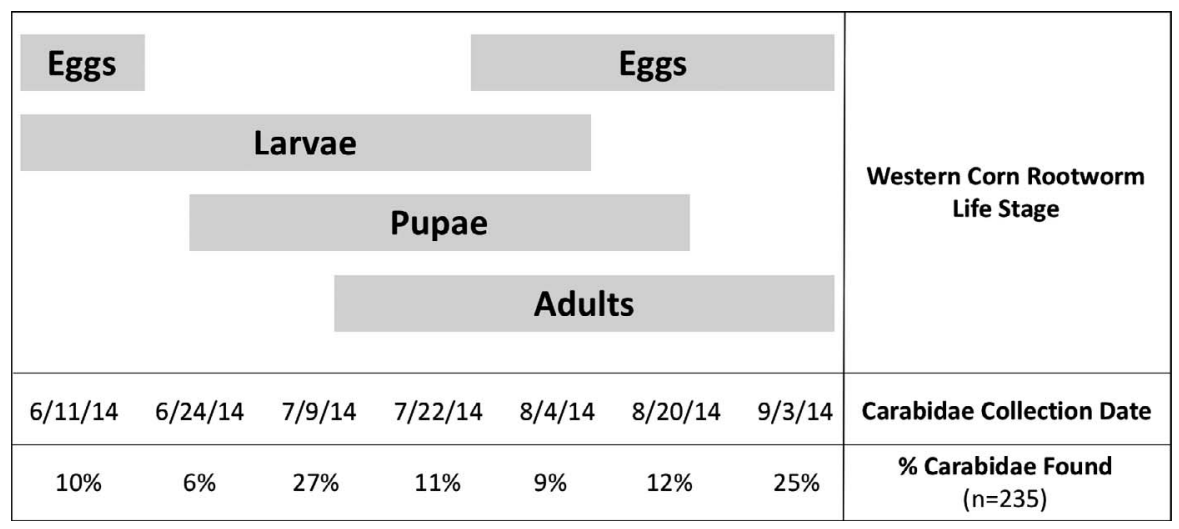

Fig. 3. Approximate western corn rootworm life stages in relation to Carabidae capture throughout the duration of this study in our field sites. Western corn rootworm estimates are based on the available literature and on the adult emergence pattern measured in this study (Figs. 1, 2). 
Table 1. Carabidae species found in dry pitfalls per field.

\begin{tabular}{|c|c|c|c|c|c|c|}
\hline \multirow[b]{2}{*}{ Species } & \multicolumn{5}{|c|}{ Field } & \multirow[b]{2}{*}{ Total } \\
\hline & A & B & C & $\mathbf{D}$ & $\mathbf{E}$ & \\
\hline Agonum extensicolle (Say) & 1 & 0 & 0 & 0 & 0 & 1 \\
\hline Agonum lutulentum Leconte & 0 & 0 & 0 & 3 & 0 & 3 \\
\hline Agonum placidum (Say) & 1 & 0 & 0 & 1 & 0 & 2 \\
\hline Agonum sp. Bonelli & 0 & 2 & 0 & 2 & 0 & 4 \\
\hline Anisodactylus carbonarius (Say) & 0 & 2 & 0 & 0 & 0 & 2 \\
\hline Anisodactylus laetus Dejean & 1 & 1 & 0 & 0 & 0 & 2 \\
\hline Anisodactylus merula (Germar) & 0 & 1 & 0 & 0 & 0 & 1 \\
\hline Anisodactylus sanctaecrucis (F.) & 0 & 63 & 1 & 1 & 0 & 65 \\
\hline Athrostictus punctatulus (Putzeys) & 1 & 2 & 0 & 0 & 0 & 3 \\
\hline Bembidion constrictum LeConte & 1 & 0 & 0 & 0 & 0 & 1 \\
\hline Bembidion mundum (LeConte) & 0 & 0 & 0 & 0 & 1 & 1 \\
\hline Bembidion quadrimaculatum Say & 6 & 2 & 23 & 5 & 3 & 39 \\
\hline Bembidion rapidum (LeConte) & 0 & 0 & 0 & 1 & 1 & 2 \\
\hline Calathus opaculus LeConte & 0 & 0 & 0 & 2 & 0 & 2 \\
\hline Callisthenes affinis Chaudoir & 0 & 0 & 0 & 1 & 0 & 1 \\
\hline Carabus serratus Say & 0 & 0 & 1 & 1 & 0 & 2 \\
\hline Chlaenius tricolor Dejean & 1 & 0 & 0 & 0 & 0 & 1 \\
\hline Cicindela punctulata Olivier & 0 & 0 & 0 & 0 & 4 & 4 \\
\hline Elaphropus anceps LeConte & 5 & 7 & 12 & 20 & 7 & 51 \\
\hline Harpalus affinis (Schrank) & 1 & 4 & 0 & 0 & 1 & 6 \\
\hline Harpalus amputatus Say & 2 & 0 & 0 & 0 & 0 & 2 \\
\hline Harpalus compar LeConte & 0 & 0 & 0 & 0 & 1 & 1 \\
\hline Harpalus erraticus Say & 0 & 1 & 0 & 0 & 0 & 1 \\
\hline Harpalus erythropus Dejean & 2 & 0 & 0 & 0 & 0 & 2 \\
\hline Harpalus faunus Say & 0 & 1 & 0 & 0 & 0 & 1 \\
\hline Harpalus herbivagus Say & 0 & 3 & 1 & 4 & 0 & 8 \\
\hline Harpalus pensylvanicus (DeGeer) & 0 & 6 & 0 & 0 & 1 & 7 \\
\hline Harpalus seclusus Casey & 1 & 2 & 0 & 0 & 0 & 3 \\
\hline Harpalus somnulentus Dejean & 1 & 2 & 0 & 0 & 1 & 4 \\
\hline Lachnocrepis parallela (Say) & 1 & 1 & 0 & 0 & 0 & 2 \\
\hline
\end{tabular}


Table 1. Continued.

\begin{tabular}{lcccccr}
\hline \hline \multirow{2}{*}{\multicolumn{1}{c}{ Species }} & \multicolumn{5}{c}{ Field } \\
\cline { 2 - 6 } & A & B & C & D & E & Total \\
\hline Lebia viridis Say & 0 & 0 & 0 & 1 & 0 & 1 \\
Poecilus chalcites (Say) & 0 & 0 & 1 & 0 & 0 & 1 \\
Poecilus lucublandus (Say) & 0 & 1 & 0 & 0 & 0 & 1 \\
Stenolophus comma (F.) & 0 & 3 & 1 & 1 & 0 & 5 \\
Stenolophus fuliginosus Dejean & 1 & 0 & 0 & 0 & 0 & 1 \\
Tachys scitulus (LeConte) & 0 & 0 & 0 & 0 & 2 & 2 \\
Total & 26 & 104 & 40 & 43 & 22 & 235 \\
Percentage & $11.1 \%$ & $44.2 \%$ & $17 \%$ & $18.3 \%$ & $9.4 \%$ & $100 \%$ \\
\hline
\end{tabular}

of western Nebraska. Few studies have focused on investigating the community of ground beetles present in Nebraska. In corn, Hariharan (1988) reported seven species in Clay County (south-central Nebraska) that were also found in our study: Agonum placidum (Say), B. quadrimaculatum, Bembidion rapidum (LeConte), E. anceps, Harpalus pensylvanicus (DeGeer), Poecilus lucublandus (Say), and $P$. chalcites. In addition, Pretorius et al. (2017) reported 13 species in common with this study from sugarbeet (Beta vulgaris L. var. vulgaris) plots in Scotts Bluff County (far western Nebraska): the species listed above, and Anisodactylus carbonarius (Say), Harpalus amputatus Say, Harpalus erraticus Say, Harpalus herbivagus Say, Harpalus somnulentus Dejean, and Stenolophus comma F. The relatively low overlap of species recovered in pitfall traps among the three studies (7 of 93 total species collected at all sites) indicates that the diversity of carabid species is quite high across Nebraska and that ground beetles are common members of agroecosystems.

Increasing the understanding of biological control services in commercial agricultural fields may provide complementary pest management tactics, as biological control and Bt traits are generally regarded as compatible (Romeis et al. 2006). All fields had high densities of carabids (Table 1), which suggests that predator trends were not adversely affected by Bt traits expressed in the field sites. This finding is supported by studies that found Bt fields allow abundant communities of naturally occurring predators to exist because of the reduction in insecticide applications (Ahmad et al. 2006, de la Poza et al. 2005, Lu et al. 2012, Marvier et al. 2007, Svobodová et al. 2017). Moreover, western corn rootworm resistance to Cry3Bb1 in the area of this study (Wangila et al. 2015) stresses even more the need for complementary $D$. $v$. virgifera controls in the region and hence the need for studies like this.

The carabid sampling period in this study (June-September) covered all life stages of the D. v. virgifera (Fig. 3). In Nebraska, egg hatch occurs between late 
May and June (Meinke et al. 2009). Larvae go through three instars and each instar takes about 1 week to develop. Third-instar D. v. virgifera create an earthen pupal cell in which they develop into adults. Pupation often occurs during the mid-June to late August period with a duration of around 5-10 d (Fisher 1986). Adult emergence takes place from July through September, and egg oviposition occurs 9-22 d after mating (Hill 1975). Therefore, the ground beetles analyzed in this study most likely encountered different stages of $D$. $v$. virgifera on different dates during the season. Absence of $D$. $v$. virgifera prey was expected in Field $E$ (first-year corn field), which yielded $9 \%$ of the carabid samples (Table 1). However, it was expected that predation would be detected in fields $\mathrm{A}$ and $\mathrm{C}$, which were the high rootworm pressure fields (Figs. 1,2). Western corn rootworms are considered suboptimal prey items for predators, as their consumption is correlated with the increase in predator community abundance (Lundgren and Fergen 2014). Hence, it is possible that the abundance of Carabidae in our fields was low enough that predators were not driven to eating nonpreferred items. It is also highly probably that other, more preferred prey items or nonprey food were in adequate abundance in the fields sampled.

In general, ground beetles have extremely diverse diets and many are polyphagous, opportunistic feeders (Holland and Luff 2000). Reviewing the most abundant species in our traps, we notice that $A$. sanctaecrucis is primarily a granivore, although it does exhibit polyphagy (Hagley et al. 1982, Lundgren and Rosentrater 2007, Blubaugh et al. 2016). Elaphropus anceps and B. quadrimaculatum are primarily predators, but the latter feeds on plant tissue as well (Brousseau et al. 2018, Fox et al. 2005, Kamenova et al. 2015). Anisodactylus sanctaecrucis abundance was primarily driven by Field B (Table 1), as 63 of 65 total specimens were found at that field. Field $B$ had a high density of weeds across the field, so it is possible that weed seeds supported $A$. sanctaecrucis densities, as activity-density of this species has been observed to be higher in plots where weed seeds were added (Blubaugh et al. 2016).

Contrary to our study, the species $A$. placidum, B. quadrimaculatum, B. rapidum, $H$. pensylvanicus, $P$. chalcites, and $S$. comma have all tested positive for $D$. $v$. virgifera DNA in other studies (Lundgren et al. 2009, Lundgren and Fergen 2011, 2014). It is unclear why all carabid specimens tested negative for $D$. $v$. virgifera DNA in this study but a number of factors may have been involved. With the exception of $B$. quadrimaculatum, sample sizes of each of the species mentioned above were very low in our study (range 1-7; Table 1) and the total carabid sample size analyzed was much smaller than that analyzed by Lundgren et al. (2009) in South Dakota (235 vs. 432, respectively). This may have affected our ability to detect $D$. v. virgifera feeding. Poecilus chalcites and Scarites quadriceps were reported by Lundgren et al. (2009) to have the highest taxon-specific frequency of D. v. virgifera feeding detection (17.5 and $20.4 \%$, respectively). Both of these are burrowing species, which could enhance encounters with $D$. v. virgifera eggs or larvae. Only one $P$. chalcites specimen was collected in this study and no Scarites species (Table 1). It is interesting to note that $P$. chalcites and Scarites quadriceps were collected by Lundgren et al (2009) in eastern South Dakota and by Hariharan (1988) in south-central Nebraska but were not found in western Nebraska by Pretorius et al. (2017) or in our study. Kirk (1975) found $P$. chalcites primarily in southeastern South Dakota in poorly drained soils capable of retaining soil 
moisture. Nebraska appears to be on the western edge of the U.S. distribution of this species (Bousquet 2012, Kirk 1975) which can be very common in agroecosystems in lowa (Esau 1968) and Illinois (Lundgren et al. 2006). Clay loam or silty clay loam soils are common in eastern Nebraska and eastern South Dakota (Elder 1969, Westin et al. 1951). Soil type and associated microhabitat may be limiting Poecilus and Scarites in western Nebraska where coarse soils (high sand content) are common (Elder 1969).

When comparing Lundgren et al. (2009) and Lundgren and Fergen (2014) to our study, methodology differences may also account for differences in results. Lundgren et al. (2009) used pitfall traps to collect predators but included larval and adult carabids in gut analyses, which may have revealed $D$. $v$. virgifera feeding not recorded in our study. Our study used natural levels of $D$. v. virgifera infestations in continuous corn, whereas Lundgren and Fergen (2014) artificially infested firstyear corn. It is possible that artificially infested eggs were more concentrated and readily available near the surface for those predators on the top soil layers. Moreover, Lundgren and Fergen (2014) used 10-cm soil cores for predator sampling, the same depth where the majority of $D$. v. virgifera eggs are found (Gray et al. 1992), while our dry pitfalls selected only for surface-dwelling predators. Collecting predators throughout the soil core instead of focusing only on surfacedwellers likely increased the chances of finding predators positive for $D$. $v$. virgifera DNA.

Another important consideration in interpretation of molecular gut-content analysis results is the detection window of the tool used (Greenstone et al. 2014). The detectability half-life for carabid predators using various prey-specific PCR primers can range significantly. Short detection windows occur (e.g., Eskelson et al. 2011 reported a 5.4-h half-life), but half-lives of $24 \mathrm{~h}$ or greater are more commonly reported for carabid predators (e.g., Renkema et al. 2014 and studies reviewed by Greenstone et al. 2014). Similarly, preliminary tests with the primers in this study indicate a half-life of approximately $24 \mathrm{~h}$ (Peterson 2012). Therefore, some carabid feeding on $D$. v. virgifera may go undetected because of the short detection window, especially if the frequency of carabid predation is rare.

Anecdotal observations by Kirk (1982) suggest that carabids prey on rootworms only during chance encounters. This agrees with other papers that only found a small percentage of total carabid specimens testing positive for $D$. v. virgifera DNA (Lundgren et al. 2009, Lundgren and Fergen 2014). The negative results from the present study support the conclusion that soil surface-dwelling adult carabids uncommonly use $D$. v. virgifera larvae, pupae, and adults as food in cornfields. However, the trophic web of $D$. $v$. virgifera is still poorly understood. There is a continued need to describe natural enemies that are effective mortality agents of $D$. $v$. virgifera that can be used for biological control and IPM programs. Various arthropods have been identified as egg or larval Diabrotica predators in other systems (Brust and House 1990, Lundgren et al. 2009), suggesting the potential value of broader exploration in western Nebraska. Documentation of the availability and efficacy of native $D$. $v$. virgifera natural enemies will aid in the development of sound conservation biological control programs in the state of Nebraska and beyond. 


\section{Acknowledgments}

The authors posthumously thank Larry Appel, the crop consultant who was critical in connecting the researchers with the growers and field sites. Thank you to the growers David Schmitt, Donnie Hajek, and Alex Canning for their cooperation. We are grateful for the technical assistance in the field and lab provided by Dotti Dobson, Kayla Mollet, Michael Eskelson, and Tony Adesemoye. This project is based on research that was partially supported by the Nebraska Agricultural Experiment Station with funding from the Hatch Act (Accession Number 1007272) through the USDA National Institute of Food and Agriculture.

\section{References Cited}

Ahmad, A., G.E. Wilde, R.J. Whitworth and G. Zolnerowich. 2006. Effect of corn hybrids expressing the coleopteran-specific Cry3Bb1 protein for corn rootworm control on aboveground insect predators. J. Econ. Entomol. 99: 1085-1095.

Álvarez-Alfageme, F., F. Ortego and P. Castañera. 2009. Bt maize fed prey mediated effect on fitness and digestive physiology of the ground predator Poecilus cupreus L. (Coleoptera: Carabidae). J. Insect Phys. 55: 144-150.

Arnett, R.H., Jr., and M.C. Thomas. 2000. American Beetles. Volume 1. Archostemata, Myxophaga, Adephaga, Polyphaga: Staphiliniformia. CRC Press LLC, Boca Raton, FL. pp. 32-132.

Blubaugh, C.M., J.R. Hagler, S.A Machtley and I. Kaplan. 2016. Cover crops increase foraging activity of omnivorous predators in seed patches and facilitate biological control. Agric. Ecosyst. Environ. 231: 264-270.

Bousquet, Y. 2012. Catalogue of Geadephaga (Coleoptera: Adephaga) of America, north of Mexico. ZooKeys 245: 1-1722.

Brousseau, P.-M., D. Gravel and I.T. Handa. 2018. Trait matching and phylogeny as predictors of predator-prey interactions involving ground beetles. Funct. Ecol. 32: 192202.

Brust, G.E. and G.J. House. 1990. Effects of soil moisture, no-tillage and predators on southern corn rootworm (Diabrotica undecimpunctata howardi) survival in corn agroecosystems. Agric. Ecosystems Environ. 31: 199-216.

Clark, T.L. and B.E. Hibbard. 2004. Comparison of nonmaize hosts to support western corn rootworm (Coleoptera: Chrysomelidae) larval biology. Environ. Entomol. 33: 681-689.

de la Poza, M., X. Pons, G.P. Farinós, C. López, F. Ortego, M. Eizaguirre, P. Castañera and R. Albajes. 2005. Impact of farm-scale Bt maize on abundance of predatory arthropods in Spain. Crop Prot. 24: 677-684.

Duan, J.J., M.S. Paradise, J.G. Lundgren, J.T Bookout, C. Jiang and R.N. Wiedenmann. 2006. Assessing nontarget impacts of Bt corn resistant to corn rootworms: Tier-1 testing with larvae of Poecilus chalcites (Coleoptera: Carabidae). Environ. Entomol. 35: 135-142.

Elder, J.A. 1969. Soils of Nebraska. Univ. of Nebr. Conservation and Survey Division. Report 444.

Esau, K.L. 1968. Carabidae (Coleoptera) and other arthropods collected in pitfall traps in lowa cornfields, fencerows, and prairies. PhD Dissertation. Iowa State Univ., Ames.

Eskelson, M.J., E.G. Chapman, D.D. Archbold, J.J. Obrycki and J.D. Hardwood. 2011. Molecular identification of predation by carabid beetles on exotic and native slugs in a strawberry agroecosystem. Biol. Control 56: 245-253.

Fisher, J.R. 1986. Development and survival of pupae of Diabrotica virgifera virgifera and $D$. undecimpunctata howardi (Coleoptera: Chrysomelidae) at constant temperatures and humidities. Environ. Entomol. 15: 626-630.

Folmer, O., M. Black, W. Hoeh, R. Lutz and R. Vrijenhoek. 1994. DNA primers for amplification of mitochondrial cytochrome $\mathrm{c}$ oxidase subunit I from diverse metazoan invertebrates. Mol. Mar. Biol. Biotech. 3: 294-299. 
Fox, T.B., D.A. Landis, F.F. Cardoso and C.D. DiFonzo. 2005. Impact of predation on establishment of the soybean aphid, Aphis glycines in soybean, Glycine max. BioControl 50: 545-563.

French, B.W., L.D. Chandler, M.M. Ellsbury, B.W. Fuller and M. West. 2004. Ground beetle (Coleoptera: Carabidae) assemblages in a transgenic corn-soybean cropping system. Environ. Entomol. 33: 554-563.

Gassmann, A.J., J.L. Petzold-Maxwell, E.H. Clifton, M.W. Dunbar, A.M. Hoffmann, D.A. Ingber and R.S. Keweshan. 2014. Field-evolved resistance by western corn rootworm to multiple Bacillus thuringiensis toxins in transgenic maize. Proc. Natl. Acad. Sci. U. S. A. 111: 5141-5146.

Gassmann, A.J., J.L. Petzold-Maxwell, R.S. Keweshan and M.W. Dunbar. 2011. Fieldevolved resistance to Bt maize by western corn rootworm. PLoS ONE 6: e22629.

Gassmann, A.J., R.B Shrestha, S.R.K. Jakka, M.W. Dunbar, E.H. Clifton, A.R. Paolino, D.A. Ingber, B.W. French, K.E Masloski, J.W. Dounda and C.R.S. Clair. 2016. Evidence of resistance to Cry34/35Ab1 corn by western corn rootworm (Coleoptera: Chrysomelidae): Root injury in the field and larval survival in plant-based bioassays. J. Econ. Entomol. 109: 1872-1880.

Gray, M.E., G.L. Hein, M.A. Boetel and D.D. Walgenbach. 1992. Western and northern corn rootworm (Coleoptera: Chrysomelidae) egg densities at three soil depths: Implications for future ecological studies. J. Kans. Entomol. Soc. 65: 354-356.

Gray, M.E., T.W. Sappington, N.J. Miller, J. Moeser and M.O. Bohn. 2009. Adaptation and invasiveness of western corn rootworm: Intensifying research on a worsening pest. Annu. Rev. Entomol. 54: 303-321.

Greenstone, M.H., M.E. Payton, D.C. Weber and A.M. Simmons. 2014. The detectability half-life in arthropod predator-prey research: What it is, why we need it, how to measure it, and how to use it. Mol. Ecol. 23: 3799-3813.

Hagley, E.A.C., N.J. Holliday and D.R. Barber. 1982. Laboratory studies of the food preferences of some orchard carabids (Coleoptera: Carabidae). Can. Entomol. 114: 431437.

Hariharan, M.J. 1988. Effect of chlorpyrifos on selected ground-dwelling beetles (Carabidae) in a cornfield. MS Thesis. University of Nebraska-Lincoln.

Hein, G.L. and J.J. Tollefson. 1985. Use of the Pherocon AM trap as a scouting tool for predicting damage by corn rootworm (Coleoptera: Chrysomelidae) larvae. J. Econ. Entomol. 78: 200-203.

Hill, R.E. 1975. Mating, oviposition patterns, fecundity and longevity of the western corn rootworm. J. Econ. Entomol. 68: 311-315.

Hitchon, A.J., J.L. Smith, B.W. French and A.W. Schaafsma. 2015. Impact of the Bt corn proteins Cry34/35Ab1 and Cry3Bb1, alone or pyramided, on western corn rootworm (Coleoptera: Chrysomelidae) beetle emergence in the field. J. Econ. Entomol. 108: 19861993.

Holland, J.M. and M.L. Luff. 2000. The effects of agricultural practices on Carabidae in temperate agroecosystems. Integ. Pest Manag. Rev. 5: 109-129.

Kamenova, S., K. Tougeron, M. Cateine, A. Marie and M. Plantegenest. 2015. Behaviourdriven micro-scale niche differentiation in carabid beetles. Entomol. Exp. Appl. 155: 39-46.

Kirk, V.M. 1975. Biology of Pterostichus chalcites, a ground beetle of cropland. Ann. Entomol. Soc. Amer. 68: 855-858.

Kirk, V.M. 1982. Carabids: Minimal role in pest management of corn rootworms. Environ. Entomol. 11: 5-8.

Kromp, B. 1999. Carabid beetles in sustainable agriculture: A review on pest control efficacy, cultivation impacts and enhancement. Agric. Ecosyst. Environ.74: 187-228.

KuhImann, U. and W.A.C.M. Van der Burgt. 1998. Possibilities for biological control of the western corn rootworm, Diabrotica virgifera virgifera LeConte, in Central Europe. Biocontrol News Info. 19(2): 59-68. 
Leslie, T.W., D.J. Biddinger, C.A. Mullin and S.J. Fleischer. 2009. Carabidae population dynamics and temporal partitioning: Response to coupled neonicotinoid-transgenic technologies in maize. Environ. Entomol. 38: 935-943.

Levine, E., J.L. Spencer, S.A. Isard, D.W. Onstad and M.E. Gray. 2002. Adaptation of the western corn rootworm to crop rotation: Evolution of a new strain in response to a management practice. Am. Entomol. 48: 94-107.

Lindroth, C.H. 1961-1969. The ground-beetles (Carabidae, excluding Cicindelinae) of Canada and Alaska, parts 1-6. Opuscula Entomologica Supplementa XX, XXIV, XXIX, XXXIII, XXXV.

Lövei, G.L. and K.D. Sunderland. 1996. Ecology and behavior of ground beetles (Coleoptera: Carabidae). Annu. Rev. Entomol. 41: 231-256.

Lu, Y., K. Wu, Y. Jiang, Y. Guo and N. Desneux. 2012. Widespread adoption of Bt cotton and insecticide decrease promotes biocontrol services. Nature 487: 362-365.

Lundgren, J.G., M.E. Ellsbury and D.A. Prischmann. 2009. Analysis of the predator community of a subterranean herbivorous insect based on polymerase chain reaction. Ecol. Appl. 19: 2157-2166.

Lundgren, J.G. and J.K. Fergen. 2011. Enhancing predation of a subterranean insect pest: A conservation benefit of winter vegetation in agroecosystems. Appl. Soil Ecol. 51: 9-16.

Lundgren, J.G. and J.K. Fergen. 2014. Predator community structure and trophic linkage strength to a focal prey. Mol. Ecol. 23: 3790-3798.

Lundgren, J.G. and K.A. Rosentrater, 2007. The strength of seeds and their destruction by granivorous insects. Arthropod-Plant Inte. 1: 93-99.

Lundgren, J.G., J.T. Shaw, E.R. Zaborski and C.E. Eastman. 2006. The influence of organic transition systems on beneficial ground-dwelling arthropods and predation of insects and weed seeds. Agric. Food Systems 21: 227-237.

Marvier, M., C. McCreedy, J. Regetz and P. Kareiva. 2007. A meta-analysis of effects of Bt cotton and maize on nontarget invertebrates. Science 316: 1475-1477.

McCravy, K.W. and J.G. Lundgren. 2011. Carabid beetles (Coleoptera: Carabidae) of the midwestern United States: A review and synthesis of recent research. Terr. Arthropod Rev. 4: 63-94.

Meinke, L.J., T.W. Sappington, D.W. Onstad, T. Guillemaud, N.J. Miller, J. Komáromi, N. Levay, L. Furlan, J. Kiss and F. Toth. 2009. Western corn rootworm (Diabrotica virgifera virgifera LeConte) population dynamics. Agric. For. Entomol. 11: 29-46.

Meinke, L.J., B.D. Siegfried, R.J. Wright and L.D. Chandler. 1998. Adult susceptibility of Nebraska western corn rootworm (Coleoptera: Chrysomelidae) populations to selected insecticides. J. Econ. Entomol. 91: 594-600.

Miller, N.J., T. Guillemaud, R. Giordano, B.D. Siegfried, M.E. Gray, L.J. Meinke and T.W. Sappington. 2009. Genes, gene flow and adaptation of Diabrotica virgifera virgifera. Agric. For. Entomol. 11: 47-60.

Mullin, C.A., M.C. Saunders, T.W. Leslie, D.J. Biddinger and S.J. Fleischer. 2005. Toxic and behavioral effects to Carabidae of seed treatments used on Cry3Bb1- and Cry1Ab/cprotected corn. Environ. Entomol. 34: 1626-1636.

Parimi, S., L.J. Meinke, B.W. French, L.D. Chandler and B.D. Siegfried. 2006. Stability and persistence of aldrin and methyl-parathion resistance in western corn rootworm populations (Coleoptera: Chrysomelidae). Crop Prot. 25: 269-274.

Pereira, A.E., H. Wang, S.N. Zukoff, L.J. Meinke, B.W. French and B.D. Siegfried. 2015. Evidence of field-evolved resistance to bifenthrin in western corn rootworm (Diabrotica virgifera virgifera LeConte) populations in western Nebraska and Kansas. PLoS ONE 10: e0142299.

Peterson, J.A. 2012. Delineating the influence of genetically modified crops and non-prey food resources on generalist predator food webs. PhD Dissertation. University of Kentucky, Lexington, Kentucky, USA.

Peterson, J.A., J.J. Obrycki and J.D. Harwood. 2009. Quantification of Bt-endotoxin exposure pathways in carabid food webs across multiple transgenic events. Biocontrol Sci. Technol. 19: 613-625. 
Pierce, C.M.F. and M.E. Gray. 2007. Population dynamics of a western corn rootworm (Coleoptera: Chrysomelidae) variant in east central Illinois commercial maize and soybean fields. J. Econ. Entomol. 100: 1104-1115.

Pretorius, R.J., G.L. Hein, E.E. Blankenship, F.F. Purrington and J.D. Bradshaw. 2017. Response of Pemphigus betae (Hemiptera: Aphididae) and beneficial epigeal arthropod communities to sugarbeet plant density and seed-applied insecticide in western Nebraska. Environ. Entomol. 46: 107-117.

Renkema, J.M., G.C. Cutler and K. Rutherford. 2014. Molecular analysis reveals lowbush blueberry pest predation rates depend on ground beetle (Coleoptera: Carabidae) species and pest density. Biocontrol 59: 749-760.

Romeis, J., M. Meissle and F. Bigler. 2006. Transgenic crops expressing Bacillus thuringiensis toxins and biological control. Nat. Biotechnol. 24: 63-71.

Souza, D., B.C. Vieira, B.K. Fritz, W.C. Hoffmann, J.A. Peterson, G.R. Kruger and L.J. Meinke. 2019. Western corn rootworm pyrethroid resistance confirmed by aerial application simulations of commercial insecticides. Sci. Rep. 9: 6713.

Svobodová, Z., Y. Shu, O.S. Habuštová, J. Romeis and M. Meissle. 2017. Stacked Bt maize and arthropod predators: exposure to insecticidal Cry proteins and potential hazards. Proc. R. Soc. B 284: 20170440.

Toepfer, S., T. Haye, M. Erlandson, M. Goettel, J.G. Lundgren, R.G. Kleespies, D.C. Weber, G.C. Walsh, A. Peters, R.U. Ehlers, H. Strasser, D. Moore, S. Keller, S. Vidal and U. Kuhlmann. 2009. A review of the natural enemies of beetles in the subtribe Diabroticina (Coleoptera: Chrysomelidae): Implications for sustainable pest management. Biocontrol Sci. Technol. 19: 1-65.

Tripathi, R.C. 2006. Negative binomial distribution. Encyclopedia of Statistical Sciences, Major Reference Works. doi: 10.1002/0471667196.ess1766.pub2.

USDA-National Agricultural Statistics Service. 2017. Crop Production 2017 Summary. 4 April 2018. (https://www.nass.usda.gov/Publications/Todays_Reports/reports/crop1117. pdf).

Wangila, D.S., A.J. Gassmann, J.L. Petzold-Maxwell, B.W. French and L.J. Meinke. 2015. Susceptibility of Nebraska western corn rootworm (Coleoptera: Chrysomelidae) populations to Bt corn events. J. Econ. Entomol. 108: 742-751.

Westin, F.C., A.J. Klingelhoets and G.B. Lee. 1951. Soils of South Dakota. South Dakota State Univ. Agric. Exp. Sta. Circulars, Paper 85.

Zukoff, S.N., K.R. Ostlie, B. Potter, L.N. Meihls, A.L. Zukoff, L. French, M.R. Ellersieck, B.W. French and B.E. Hibbard. 2016. Multiple assays indicate varying levels of cross resistance in Cry3Bb1-Selected field populations of the western corn rootworm to mCry3A, eCry3.1Ab, and Cry34/35Ab1. J. Econ. Entomol. 109: 1387-1398. 